\title{
Inguinal Endometriosis Visualized on I-I3I Whole Body Scan
}

\author{
|-13| Tüm Vücut Taramada Inguinal Endometriozis Görünümü
}

\section{(1) Derya Çayırl, (10) Mine Arazl, (1) Mahmut Apaydın², (10) Erman Çakal2}

IUniversity of Health Sciences, Dışkapı Yıldırım Beyazıt Training and Research Hospital, Clinic of Nuclear Medicine, Ankara, Turkey

2University of Health Sciences, Dışkapı Yıldırım Beyazıt Training and Research Hospital, Clinic of Endocrinology and Metabolism, Ankara, Turkey

\begin{abstract}
We present a rare case with inguinal iodine-131 (I-131) uptake on whole body scan. The patient was suffering from a painful right inguinal mass during menstrual period, which was later sonographically and histopathologically confirmed to be an inguinal focus of endometriosis. Endometriosis is a previously reported site of radioiodine uptake and detection of radioiodine uptake in the inguinal region has also been described. Nevertheless, to the best of our knowledge, this is the first case report of I-131 uptake in an inguinal endometriosis focus. History and physical examination of the patient are both very important in identifying the etiology of the ectopic uptake sites on I-131 whole body scan, and inguinal endometriosis should be kept in mind while reporting inguinal radioiodine uptake on I-131 whole body scan.
\end{abstract}

Keywords: Endometriosis, whole body imaging, iodine-131

\section{Öz}

Bu raporda iyot-131 (I-131) tüm vücut taramada inguinal bölgede tutulum saptanan nadir bir olguyu sunuyoruz. Menstrüel siklus sırasında ağrılı inguinal kitle şikayeti olan hastada, kitlenin daha sonra sonografik ve histopatolojik olarak inguinal endometriozis odağına ait olduğu konfirme edildi. Endometrioziste radyoaktif iyot tutulumu ve inguinal bölgede radyoaktif iyot tutulumunun saptanması daha önce bildirilmiştir; ancak inguinal endometriozis odağında l-131 tutulumu, bildiğimiz kadarıyla, ilk kez bu olguda sunulmaktadır. I-131 tüm vücut taramada ektopik tutulum alanlarının etiyolojisinin çözülmesinde hasta öyküsü ve fizik muayene çok önemli olup, I-131 tüm vücut taramada inguinal bölgede radyoaktif iyot tutulumu raporlanırken inguinal endometriozis de akılda bulundurulmalıdır.

Anahtar kelimeler: Endometriozis, tüm vücut görüntüleme, iyot-131

Address for Correspondence: Derya Çayır MD, University of Health Sciences, Dışkapı Yıldırım Beyazıt Training and Research Hospital, Clinic of Nuclear Medicine, Ankara, Turkey

Phone: +90 5355681066 E-mail: drderyaors@hotmail.com ORCID ID: orcid.org/0000-0002-7756-3210

Received: 27.04.2017 Accepted: 15.10.2017

${ }^{\circ}$ Copyright 2018 by Turkish Society of Nuclear Medicine

Molecular Imaging and Radionuclide Therapy published by Galenos Yayınevi. 

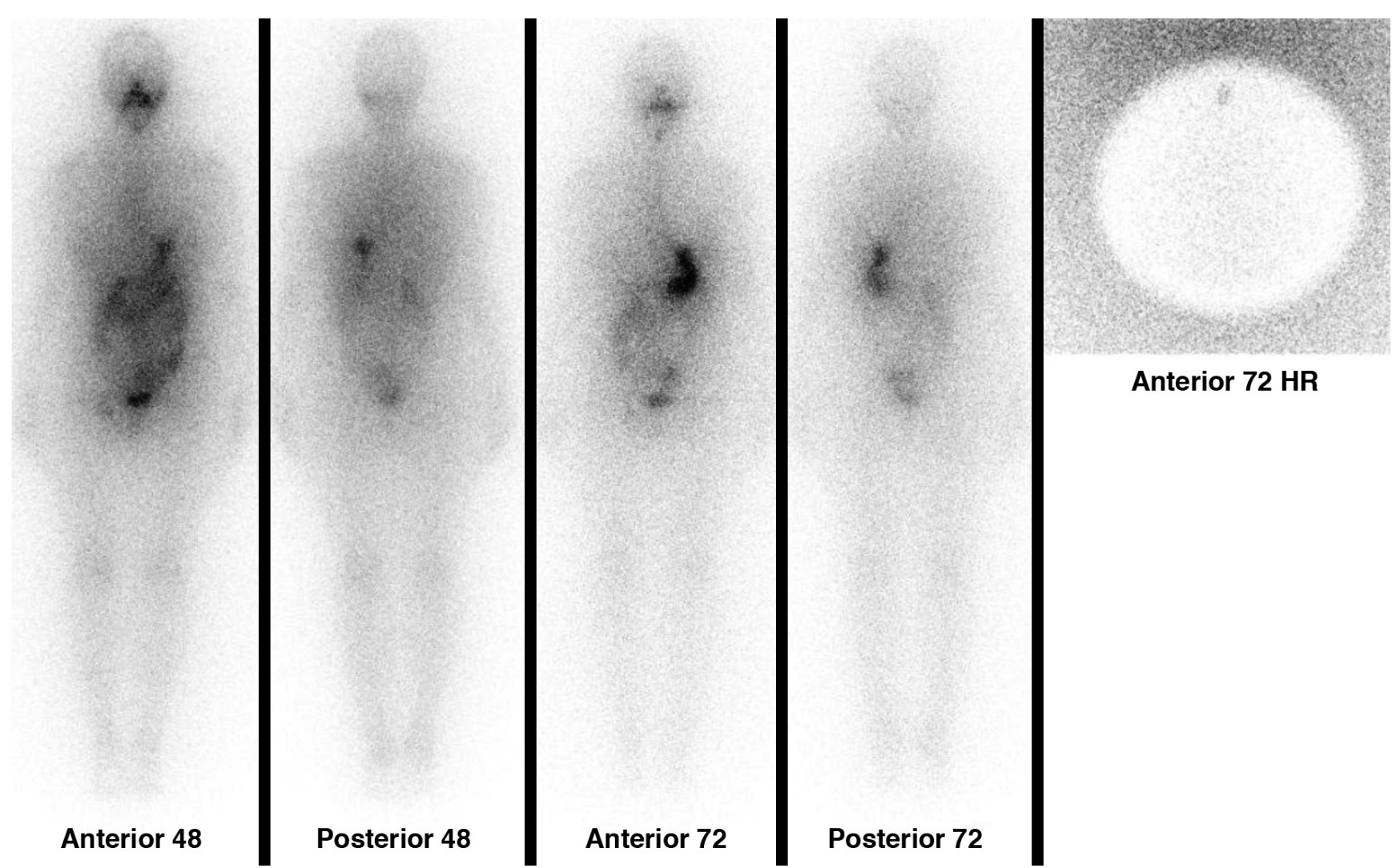

Anterior $72 \mathrm{HR}$

Figure 1. A 35-year-old woman with papillary thyroid carcinoma who had received 50 mCi iodine-131 (I-131) following total thyroidectomy underwent an I-131 whole body scan one year later. While serum levels of thyrotrophin-stimulating hormone was $92.22 \mathrm{mIU} / \mathrm{L}$, thyroglobulin and anti-thyroglobulin antibody levels were $4.61 \mathrm{ng} / \mathrm{mL}$ and $<0.9 \mathrm{IU} / \mathrm{mL}$, respectively. $1-131$ whole body images were obtained by using a large field-of-view gamma camera (Siemens e.cam-signature; Siemens, Hoffmann Estates, Illinois, United States of America) in a 256×1024 matrix using a high energy parallel hole collimator and pinhole collimator at 48 and 72 hours. Images showed focal I-131 accumulation on the neck, located in the midline, along with I-131 uptake in the right inguinal region and the suprapubic area (Figure 1). The focal uptake on the neck was interpreted as residual thyroid tissue on the thyroglossal duct, and the suprapubic non-homogenous activity was attributed to uterine activity due to menstrual bleeding. The etiology of the right inguinal uptake was revealed with further evaluation. The patient was also suffering from groin pain during the menstrual period along with a right inguinal mass that enlarged at the same time. Right inguinal superficial ultrasound revealed a hypoechoic solid mass of $25 \times 15 \mathrm{~mm}$ located in the neighborhood of femoral artery and multiple accompanying reactive lymph nodes with the largest dimensions measuring $43 \times 8 \mathrm{~mm}$. The Tru-Cut biopsy of the right inguinal palpable mass was performed that revealed endometriosis. Thyroglobulin elevation in our patient was associated with neck uptake and distant metastasis was excluded. Treatment was planned accordingly.

Endometriosis is the existence of endometrium, the layer surrounding the uterine cavity, anywhere in the body other than the uterus. It is mostly located in the intrapelvic region (1). Inguinal (non-cutaneous) endometriosis is a rare presentation of endometriosis, occurring in only $0.6 \%$ of women $(1,2)$. Inguinal endometriosis was first reported by Allen in $1896(3,4,5)$. Patients with inguinal endometriosis complain of inguinal mass and pain, in particular, acute pain during menstrual cycles $(2,6)$. The mechanism of iodine uptake in endometriosis is not yet clear, and iodine uptake in inguinal endometriosis has not been previously described in the literature. In our case, the scanning was performed during the patient's menstrual cycle. An increase in blood flow to the inguinal endometriosis or presence of inflammation in this area might be the reasons for increased radioiodine uptake. Hyperemia, vasodilation, local edema, and increased capillary permeability may cause increased radioiodine uptake in inflamed areas $(7,8)$. In our case, there were multiple reactive lymph nodes around the inguinal mass. Both increased blood flow and reactive lymph nodes could have led to an increased activity. In conclusion, although it is a well-established technique, one may still confront with unexpected findings on I-131 whole body scan. While reporting radioiodine uptake in the inguinal region, endometriosis should be kept in mind as a rare etiology and the patient should be further evaluated accordingly.

Focal I-131 accumulation on the neck, located in the midline, is detected along with radioiodine uptake in the right inguinal region on I-131 whole body images. 


\section{Ethics}

Informed Consent: Consent form was filled out by all participants.

Peer-review: Externally peer-reviewed.

\section{Authorship Contributions}

Surgical and Medical Practices: D.Ç., M.A., M.A., E.Ç., Concept: D.Ç., Design: D.Ç., M.A., Data Collection or Processing: D.Ç., M.A., Analysis or Interpretation: D.Ç., M.A., Literature Search: D.Ç., Writing: D.Ç.

Conflict of Interest: No conflict of interest was declared by the authors.

Financial Disclosure: The authors declared that this study received no financial support.

\section{References}

1. D'Hooghe TM, Hill JA. Endometriosis. In: Berek SJ, Adashi EY, Hillard PA, eds. Novak's Gynecology, 12th ed. Baltimore: Williams\&Wilkins;1996;887-915.
2. Bergqvist A. Extragenital endometriosis. Eur J Surg 1992;158:712.

3. Tarım E, Bağış T, Tarım A, Kıllıııdağ EB, Noyan T, Kayaselçuk F. İnguinal endometriozis: bir olgu sunumu. Türkiye Klinikleri J Gynecol Obst 2002;12:184-185.

4. Dwivedi AJ, Agrawal SN, Silva YJ. Abdominal wall endometriomas. Dig Dis Sci 2002;47:456-461.

5. Blanco RG, Parithivel VS, Shah AK, Gumbs MA, Schein M, Gerst PH. Abdominal wall endometriomas. Am J Surg 2003;185:596-598.

6. Kaushik R, Gulati A. Inguinal endometriosis: A case report. J Cytol 2008;25:73-75.

7. Garger YB, Winfeld M, Friedman K, Blum M. In thyroidectomized thyroid cancer patients, false-positive I-131 whole body scans are often caused by inflammation rather than thyroid cancer. J Investig Med High Impact Case Rep 2016;4:2324709616633715.

8. Hannoush ZC, Palacios JD, Kuker RA, Casula S. False Positive Findings on I-131 WBS and SPECT/CT in Patients with History of Thyroid Cancer: Case Series. Case Rep Endocrinol 2017;2017:8568347. 